\title{
Food Diversification: Strengthening Strategic Efforts to Reduce Social Inequality through Sustainable Food Security Development in Indonesia
}

\author{
Fajar Rahmanto, Eko Priyo Purnomo* and Aulia Nur Kasiwi \\ Department of Government Affairs and Administrations, Jusuf Kalla School of Government, Universitas \\ Muhammadiyah Yogyakarta, Yogyakarta, Indonesia \\ ${ }^{*}$ Corresponding author: eko@umy.ac.id
}

\begin{abstract}
Potential food resources can be utilized through food diversification as a part of the government's efforts to minimize socio-economic inequality with sustainable food security development program. The purpose of this study was to observe the role of food diversification in reducing social inequality through sustainable food security development. This study uses descriptive qualitative methods with secondary data collection techniques which include data references as well as documentation related to food security development. The results showed that in Indonesia, food diversification program has an impact on increasing income, household resilience and welfare with a decrease in the number of the rural poor population of $4.7 \%$ (from 16.31 people to 15.54 people). It was positively correlated with the increase in farmers' income by (IDR) 30.37 million per capita increase (4.47\%). Then, followed by the level of food security in the district area reached $80.53 \%$ (335 regions) and for urban areas amounted to $92.85 \%$ (91 regions). National food security can be achieved through maximizing the potential use of food resources at the regional level, by diversifying food based on local wisdom and optimally local resources. It can be concluded that food diversification is a policy that can be used by the government to increase community economic income and reduce poverty and social inequality.
\end{abstract}

Keywords: farm diversification; food accessibility; food availability; livelihood; resilience

Cite this as: Rahmanto, F., Purnomo, E. P., \& Kasiwi, A. N. (2021). Food Diversification: Strengthening Strategic Efforts to Reduce Social Inequality through Sustainable Food Security Development in Indonesia. Caraka Tani: Journal of Sustainable Agriculture, 36(1), 33-44. doi: http://dx.doi.org/10.20961/carakatani.v36i1. 41202

\section{INTRODUCTION}

In 2015 the United Nations (UN) has established the Sustainable Development Goals of 2030 (SDGs) with goal number two namely Zero Hunger intended to end hunger, achieve food security, improve nutrition and encourage sustainable agriculture (Hatmanto and Setyono, 2018). The UN SDGs gives food and energy security a high priority (Kline et al., 2017). The World Food Summit in 1996 defines food security as a situation where all people can have access to adequate, safe and nutritious food to meet their food needs in realizing an active and healthy life (Hadi et al., 2019).

The increasing concern about food security in food-insecure regions in the world shows the inability of a sectoral approach in dealing with agricultural problems (Bhaduri et al., 2018). Based on the Food Insecurity Experience Scale, in 2014-2016 Asia is a food-insecure area, especially in the Southeast Asia Region (Cafiero et al., 2018). The Global Hunger Index (GHI) in 2018 shows that the level of hunger and malnutrition in the world is in the serious category; including Indonesia with a GHI score of 21.9 which is in

\footnotetext{
* Received for publication April 17, 2020

Accepted after corrections September 7, 2020
} 
a state of hunger with a serious level (Hadi et al., 2019). The carrying capacity of food security is being determined by aspects of agricultural land area, food frequency, the productivity of agricultural land and also determined by the population (Sadali, 2018). So, the regulation that clear of the boundaries of community land is very important in dealing with the problem of transfer of land ownership functions (Purnomo et al., 2019). In the agriculture sector, there are still five main problems covering the agricultural land area, incentive systems, human resource capabilities, land tenure and injustice as well as higher education issues. Aside from those main problems, there is also the influence of the industrial revolution 4.0 which demanded all groups, including farmers, to change and be adaptive to the latest advancements in technology (Al-Basith, 2019).

According to the Food Security Index/GFSI which is the result of the collaboration of The Economist and food science company Corteva, shows that Indonesia's food security has indeed improved from 46.8 to 54.8 in 2018 . The majority of districts and cities in Indonesia have good food resilience, even though there are still 81 districts (19.47\%) and 7 cities (7.14\%) in Indonesia that need to get a comprehensive handling regarding the food vulnerability (Gerintya, 2019). Achieving food security and nutrition for all people is a critical challenge during global change (Müller et al., 2020).

Approaches to smallholder commercialization, agroecology and sustainability, the local economy and equity and market liberalization can be achieved by keeping the food security programs oriented to the welfare of smallholder households (Jiren et al., 2020). However, the potential tradeoff between local diversity and the efficiency of global resources needs to be better understood (Sellberg et al., 2020). Promotion of the value of sociocultural equality in access to quality food for the highest number is hindered by differences in diet and consumer culture (Fourat et al., 2020). The dynamics of food accessibility and the contribution of local factors vary significantly from time to time (Hu et al., 2020). Besides the impacts of climate change and degradation of natural resources (Mulwa and Visser, 2020), poverty are some of the main threats to food security for rural households in developing countries (Miyinzi et al., 2019).
Previous studies of food security have been carried out including Perdinan et al. (2018) on Climate Change Adaptation and Food Security Initiatives and Policy Studies which findings were that the impact of climate change has influenced the decline in productivity of agricultural products and the increase in pests of plant diseases compounded by extreme climate phenomena which poses a serious threat to crop and crop failure. The study of Waha et al. (2018) states that a more diverse agricultural system can contribute to food security for households due to the household market orientation factors and available land resources. Then a study from Larson et al. (2019) with a focus of research on the relationship between empowerment activities, food security and food diversity shows that highincome households have more diverse diets. In contrast, low-income families tend to experience moderate to moderate food insecurity weight.

Based on previous research related to food security, the authors, however, have yet to find a review article on food diversification as an effort to reduce social inequality. Food security supported by sustainable food diversification will be able to contribute in reducing social inequality, reducing poverty and improving community welfare through development in agriculture and food. The purpose of this article is to observe the role of food diversification as a strategic step by the government in reducing social inequality. Food diversification is an important thing to be studied further through this article, especially related to development of efforts in the food sector to reduce social inequality. This article has an update on reviewing food security from the perspective of the relationship between food diversification and reducing social inequalities.

\section{MATERIALS AND METHOD}

This paper uses a qualitative method with a literature study approach to obtain research data and information. Descriptive qualitative is a study conducted to provide in-depth descriptions using qualitative aspects of research (Bandur, 2019). The reason researchers use qualitative research methods because they relate to the focus of research which is to find out about how the food diversification as a strategic effort in the field of food and agriculture can be an aid in reducing social inequality in the society. 
The type of data used in this study are secondary data, in the form of documents regarding national food security development policies, national food security index data, Prevalence of Undernourishment (PoU) data, the index of Desirable Dietary Pattern (DDP), population expenditure index for food and the level of income of farmers and the level of poverty of rural populations. The data comes from the National Food Security Agency report. The data were classified, interpreted and finally concluded.

The food security index data is classified and used to see the condition of national food security, then the orientation of food policy is analyzed from the food development policy. In contrast, the PoU data, the index of DDP, the population expenditure index for food, as well as data on farmer income levels and rural population poverty levels were analyzed to determine the "relationship" between food diversification and reduction of social inequality. For the presentation of data in general in qualitative research conducted with matrices, graphs, charts and narrative texts and drawing for conclusions/ verification which is the end of the analysis of qualitative research data, carried out by the meaning through a reflection of research data.

\section{RESULTS AND DISCUSSION}

\section{Overview of food security conditions in Indonesia}

Food security conditions illustrate how much the level of food availability in an area that can be accessed to meet all of the amount of food consumed by a community. The level of food security in each region is certainly different, depending on the area of food agriculture land, food frequency, the productivity of agricultural land and population (Sadali, 2018). For the condition of food security in various regions in Indonesia can be seen in rural areas and urban areas in Table 1.

Table 1. Levels of regency and city food security in Indonesia

\begin{tabular}{lrrrr}
\hline \multirow{2}{*}{ Criteria } & \multicolumn{2}{c}{ Urban (District) } & \multicolumn{2}{c}{ Rural } \\
\cline { 2 - 5 } & Total & Percent $(\%)$ & Total & Percent (\%) \\
\hline Very vulnerable & 26 & $6.25 \%$ & 2 & $2.04 \%$ \\
Vulnerable & 21 & $5.05 \%$ & 2 & $2.04 \%$ \\
Enough vulnerable & 34 & $8.17 \%$ & 3 & $3.07 \%$ \\
Moderately resistant & 47 & $11.30 \%$ & 9 & $9.18 \%$ \\
Resistant & 137 & $32.93 \%$ & 32 & $32.65 \%$ \\
Very resistant & 151 & $36.30 \%$ & 50 & $51.02 \%$ \\
\hline \multicolumn{1}{c}{ Total } & 416 & $100.00 \%$ & 98 & $100.00 \%$ \\
\hline
\end{tabular}

Source: Analysis secondary data (BKP, 2019b)

Based on the Table 1, it can be seen that districts with a higher number of regions still have a high level of food insecurity than urban areas with 81 districts that are food insecure or reach $19.17 \%$ and 7 urban areas are still food insecure or reach $7.15 \%$. For 81 regencies that are still food insecure, 34 regions have a somewhat food insecure status, 21 regencies are food insecure and 26 other areas are categorized as highly food insecure. Then from 7 urban areas that are still food insecure, there are still 2 urban areas that are food insecure and very food insecure and 3 other urban areas that are somewhat food insecure. Food insecurity occurred in the area of civilization with a minimum space that can be used as agricultural land. At least land can be used for agriculture in cities at the level of food production. The continuous conversion of agricultural land works against the need for food commodities (Rafiuddin et al., 2016).

While the level of food security for the regency reached 335 areas or amounted to $80.53 \%$ and for urban areas as many as 91 regions had been food resistant or amounted to $92.85 \%$. From the 335 regencies that have food security, 47 regions are categorized as sufficient, 137 regions are secured and 151 other districts are categorized as highly secured. The 91 urban areas were consisted of 9 regions included in the category of moderately resistant, 32 urban areas included in the category of secured and 50 urban areas included in the category of highly secured. Food insecurity areas can be seen by mapping food from the perspective of food access (Widodo et al., 2018). 


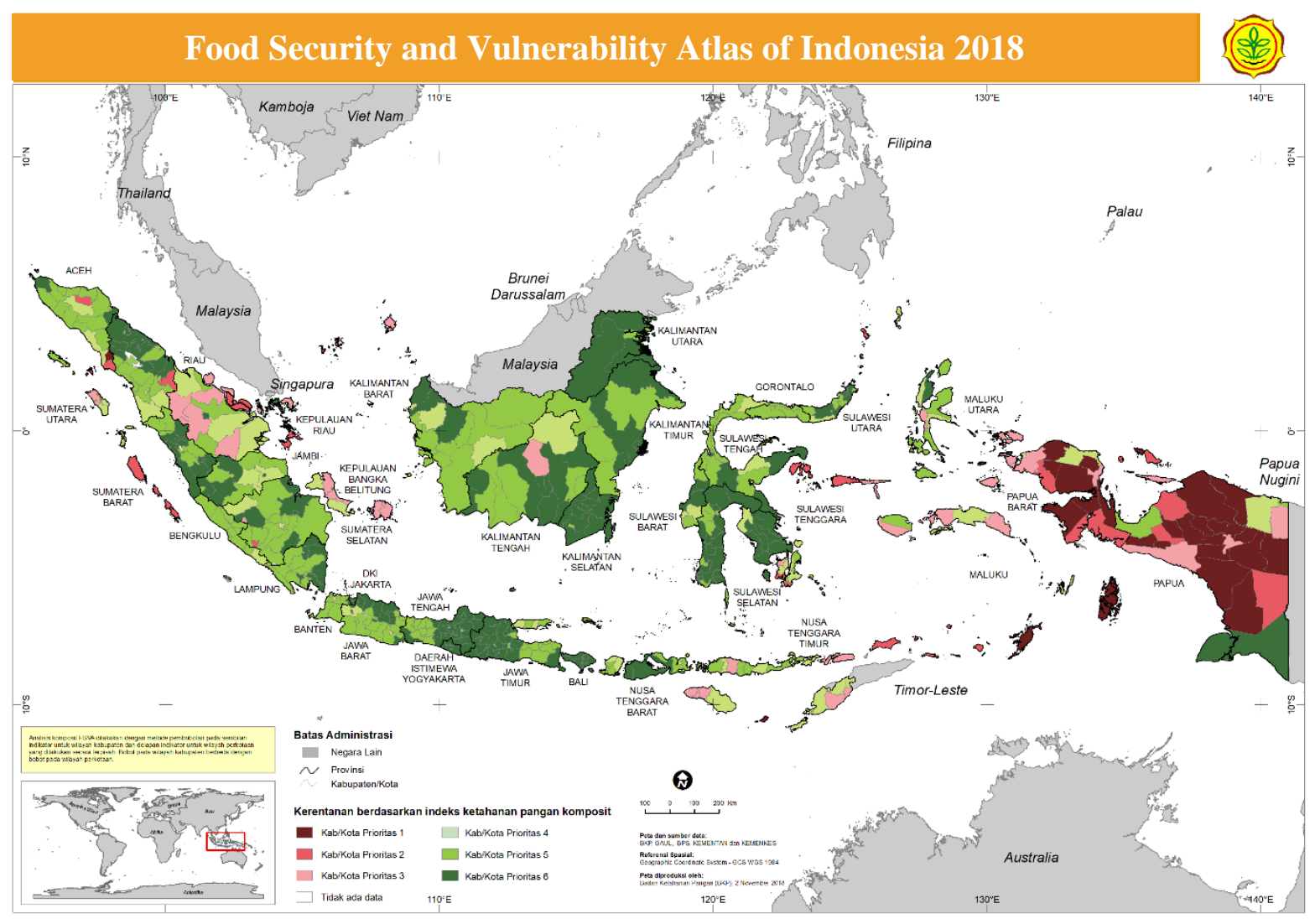

Figure 1. Map of district and city food security in Indonesia Source: Ministry of Agriculture's (BKP, 2019b)

Based on the Figure 1 about maps of Food Security and Vulnerability, which shows the distribution of food-resistant and food-insecure areas in Indonesia, the majority of regions in the western and central parts of Indonesia (Sumatra Island, Java-Bali, Borneo, Sulawesi, Nusa Tenggara and Maluku) already have higher food security levels than those in East Indonesia (Papua). This fact is influenced by the continued imbalance in the development of connecting infrastructures that serve as means of supporting the smooth distribution of food between the regions of west-central Indonesia and eastern Indonesia. Infrastructure has a strategic role in the equitable distribution of food because good infrastructure can increase people's access to affordable and also the adequate community food (Hu et al., 2020). Sources of food that are affordable and easily accessible, easily created, stabilizing food security for the community (Srinita, 2018). Distribution policy is an effective policy for food security that can be focused on stabilizing food prices (Dewi, 2018). In realizing to effective of regulating food prices, adequate infrastructure is needed (Azahari, 2016; Ilham et al., 2016).

\section{National food security development policy orientation}

In the development of food security, the state has an obligation to provide adequate food both in quantity and quality for the whole community so that it is able to meet the standard of living. The need for food is always increasing along with the increase in population. Based on the General Comment 12 of The Committee on Economic, Social and Cultural Rights (CESCR) the right of food has been recognized internationally as one of the basic human rights. Law No. 18 of 2012 about of food security to meet basic human needs, providing benefits in a fair, equitable and sustainable manner, based on food sovereignty, food independence and food security. The policy orientation of the Food Security Agency is related to strengthening food security related to food security, food affordability and food utilization. The following is one of several aspects as follows in the Table 2. 
Table 2. Main aspects in supporting national food security

\begin{tabular}{ll}
\hline \multicolumn{1}{c}{ Aspect } & \multicolumn{1}{c}{ Focus } \\
\hline Food availability & $\begin{array}{l}\text { 1. Increasing the availability of diverse food based on the potential of local } \\
\text { resources }\end{array}$ \\
& $\begin{array}{l}\text { 2. Handling food affordability physically and economically for the community } \\
\text { 3. Handling food insecurity to reduce the number of poor and hungry people }\end{array}$ \\
\hline Food distribution & $\begin{array}{l}\text { 1. Stabilizing the supply and price of food } \\
\text { Food utilization }\end{array}$ \\
& $\begin{array}{l}\text { 2. Management of food reserves } \\
\text { locelerating diversification of food consumption based on resources and }\end{array}$ \\
& 2. Supervision of the quality and safety of fresh food of plant origin \\
\hline
\end{tabular}

Source: Food Safety Agency, 2018

Based on the Table 2, it can be seen that to build food security as an effort to reduce social inequalities in the aspect of food availability, efforts to encourage increased availability of diverse food based on the potential of local resources are required. The utilization of food from potential local resources make the community has the ease of access to food and in terms of economic aspects, community is able to meet food needs at more affordable than household expenditure so that the need for food for all levels of society are guaranteed. The growing need for this type of guarantee, will certainly reduce the level of food insecurity so that cases of hunger can be reduced and can reduce the amount of poverty. Household needs will be guaranteed for each individual, then community food security will be achieved. Local food resources are potential to be developed and they will increase national food security (Rofiq and Subagi, 2016).

Food distribution aspects carried out by stabilizing the supply and price of food that is intended to create conditions that have a continuity of supply and price stability at any time in each region so as not to cause food scarcity. To guarantee price freedom and guarantee the supply of food in all regions, of course the country has a very strategic role must have a strong intervention on the pattern of food distribution to the community. Distribution policy is an effective policy because it represents the country in the distribution chain supported by food warehouses in each region, good coordination between regions, as well as the privilege of being a State Trading Company (STE) and price stabilizer (Dewi, 2018).

The aspect of food utilization is the last aspect as one part in the development of food security after the availability of food is fulfilled and the smooth distribution of food is fulfilled. In the use of food, the government supports to encourage the acceleration of diversification of food consumption based on resources and local wisdom. The occurrence of vulnerability to food security because there is no shift in the pattern of consumption of staple foods from the community to other local food sources (Umanailo, 2018).

In general, based on a review of aspects of national food security policies, it can be seen that food security is developed towards the direction of building food availability that is able to meet the needs of all levels of society based on the utilization of the potential of local resources. Later, it is followed up by ensuring the distribution of food for equitable distribution of food and food affordability for people in each region by stabilizing the amount of food supply and prices. Finally, the utilization of the potential of local food resources is carried out by increasing the diversity of food consumption to the community so that there is a shift in the pattern of consumption of staple foods to maintain the level of vulnerability to food security in each region. This is in line with the food policy objectives of President Jokowi's government which have set three main objectives, namely: to encourage the availability of food to meet people's needs; reduce poverty by increasing farmers' welfare and increasing the role and contribution of food producers to the national food needs (Saragih, 2017).

The strategic efforts of the government in building sustainable national food security in the future continue to experience changes and developments at all times. The concept of food security development has evolved by adjusting the complexity of the problems that occur from time 
to time so it needs to be done by setting strategies and policies on target (Saliem and Ariani, 2016; Hapsari and Rudiarto, 2017). An increase in land use change, lack of supervision and weak control on the ground by the government caused negative impacts (Fattah and Purnomo, 2018). Therefore, strategic efforts are needed in the development of food security as in the Table 3 .

Table 3. Strategic management of national food security development

\begin{tabular}{lc}
\hline \multicolumn{1}{c}{ Strategic } & \multicolumn{2}{c}{ Operational } \\
\hline $\begin{array}{l}\text { Priority activities in vulnerable areas to } \\
\text { food insecurity. }\end{array}$ & $\begin{array}{l}\text { 1. Preparation of availability analysis instruments, } \\
\text { national strategic food commodity needs and } \\
\text { physical and economic affordability index }\end{array}$ \\
& $\begin{array}{l}\text { 2. Community empowerment in food insecure } \\
\text { vulnerable areas }\end{array}$ \\
\hline $\begin{array}{l}\text { Improving access to community food } \\
\text { through productive agriculture-based } \\
\text { activities }\end{array}$ & $\begin{array}{l}\text { 1. Increasing the capacity and number of institutional } \\
\text { distribution and food reserves }\end{array}$
\end{tabular}

Institutional strengthening and 1 . Analysis of food supply and prices at producer and
distribution of food to maintain food
consumer levels
supply and price stability.

\begin{tabular}{ll}
\hline $\begin{array}{l}\text { Encourage the utilization and } \\
\text { management of local food sources based } \\
\text { on regional potential. }\end{array}$ & 1. The development of the local food industry \\
$\begin{array}{ll}\text { Promotion and education to the public to } \\
\text { utilize diverse, nutritionally balanced and } \\
\text { safe food. }\end{array}$ & $\begin{array}{l}\text { 1. Empowering the community to utilize B2SA's yard } \\
\text { and food consumption }\end{array}$ \\
\hline $\begin{array}{l}\text { Perform maximum control over the } \\
\text { quality and safety of fresh food of plant }\end{array}$ & $\begin{array}{l}\text { 1. Strengthening the institutional security of fresh food } \\
\text { of plant origin }\end{array}$
\end{tabular}
origin.

Source: Data analysis of the Food Safety Agency, 2018

Based on the Table 3, it can be known about the strategy in the effort to develop national food security by implementing priority activities in areas that still have a level of vulnerability and food insecurity. The operationalization of the strategy is carried out by compiling instruments of availability analysis, national strategic food commodity needs and physical and economic affordability index. These various instruments related to food insecurity information data can be used as a basis for mapping foodinsecure areas so that the implementation of priority programs for food security can be effective and on target. Food insecurity areas can be identified by mapping food security (Widodo et al., 2018).

The development of the local food industry will provide the availability of a variety of food products that can be a choice to be utilized by the community in meeting food needs. Diversification of processed foods based on local food can be carried out conventionally using simple facilities, does not require large capital, insufficient labor can be filled from the family members and raw materials originating from the local area (Hanafie et al., 2018). Potential food sources can be managed, utilized and developed to have more economic value to improve people's welfare through food diversification. Diversifying the right food will result in a diversity of food availability based on the potential of local resources in supporting food security and improving welfare (Lestari and Bambang, 2017).

\section{Increased food diversification for sustainable food security}

The implementation of increased diversification and national food security is carried out with activities or programs to develop availability and handling food insecurity, develop distribution systems and stabilize food prices and develop diversified consumption and food security. The activity has the ultimate goal of strengthening the community's food security; hence, it requires the participation and active role from all of the stakeholders from the national level to the 
local level including the community members themselves. Achievement of the success of food security is a part of strengthening food political security and national economic stability to guarantee the availability of food at prices easily accessible by the community. On the other hand, food security is also a manifestation of the nation's commitment as an active role in achieving the SDGs in reducing community inequality through actions to reduce poverty and hunger. The government is obliged to determine the partisanship step in setting food policy, supported by a firm attitude of intervention to build food independence in realizing national food security (Azahari, 2016).

The food security of a country has a strategic position as a concern of the stakeholders in determining the direction of the national food development policy. When the development of national food security is achieved, it serves as a guarantee of a country in meeting the needs of the food for all levels of society both in terms of quality and quantity. With the availability of adequate food in an area, food security can be achieved (Sadali, 2018). With the advancements in food security, there will be sufficient amount of food required by the population in the future. Making food availability a consideration for meeting the people's food needs, food security will be fulfilled (Saliem and Ariani, 2016; Sadali, 2018). However, national food availability is not necessarily a guarantee that it will provide access to food at the household level (Ilham et al., 2016).

The diversification of local food resources is a part of the efforts to strengthen food security. Local food resources can be developed and improved into food products in the field of food security for food sovereignty at national level (Rofiq and Subagi, 2016; Rusdiana and Maesya, 2017). The pattern of food diversification must be based on the utilization of all local food sources to reduce the dependence on imported food so that it will be able to increase independence based on local wisdom. But the activity of importing staple food commodities does not fully affect national food security (Damanik, 2016).

\section{Food diversification as an effort in reducing social inequality}

Social inequality and poverty are a problem for every country in the world, including Indonesia. One way of noticing social inequality is by observing the ability of households in consuming food. People with higher income levels have more diverse consumption patterns, while those who have low-income levels experience moderate to severe food insecurity (Larson et al., 2019). The PoU, which is the proportion of people who experience food consumption shortages measured from the minimum energy intake to be able to live healthy and active to the population as a whole, can be used to determine the level of social inequality.

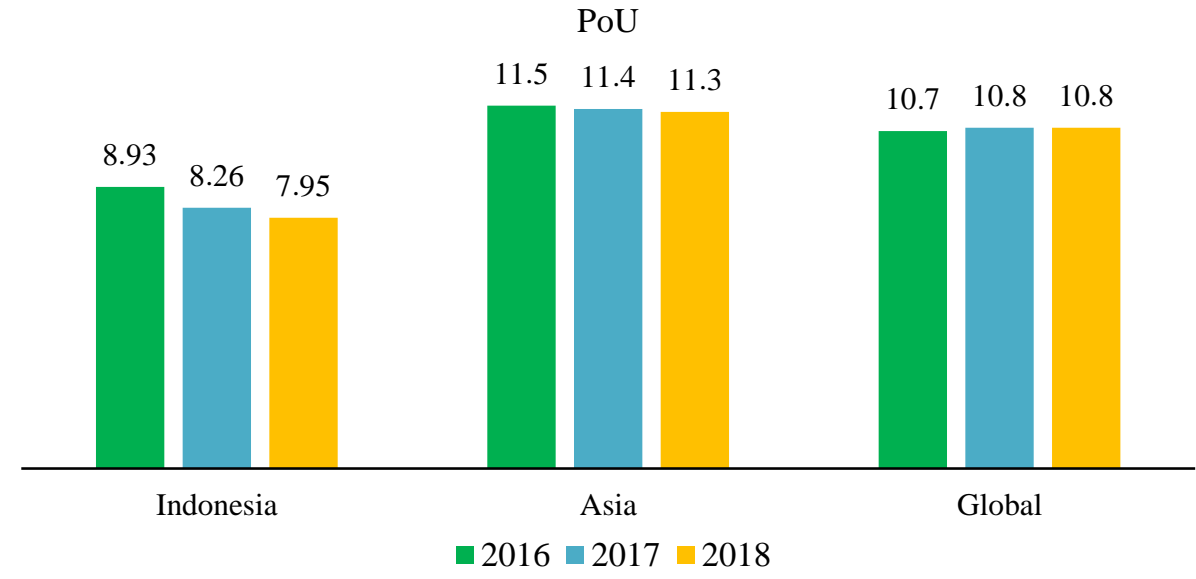

Figure 2. Indonesia index PoU

Source: FAO et al. (2018)

The Indonesian population viewed from the PoU index on food consumption shortages shows a declining trend (Figure 2). When compared with the world average, from 2016-2018, the Indonesian PoU figure was still much better with an average reaching $8.38 \%$ while the Global 
PoU from 2016-2018 was $10.8 \%$. Likewise, if compared to the Asian region in general, Indonesia's PoU figures were still considerably better. In 2016-2018, the average PoU in the Asian area was $11.4 \%$. Indonesia's PoU figures have decreased from year to year (Figure 2). The 2016 Indonesian PoU figure of $8.93 \%$ fell to $7.66 \%$ in 2019 where the decline in the PoU was also directly proportional to the decrease in population poverty by $0.41 \%$ from $9.82 \%$ in 2018 to $9.41 \%$ in 2019 (BKP, 2019b). The decreasing prevalence of food consumption indicates the increasing diversification of the available food, making it easier for people to gain access to food. Socio-cultural equality in access to quality food pragmatically depends on the application of social inclusion in food supply (Fourat et al., 2020). National prevalence rates for food shortages correlate with levels of community welfare (Cafiero et al., 2018).

Agricultural development which is well implemented will be able to increase food security, through increasing food diversification and improving access to food. Food diversification can make food availability more diverse so that access to food for the population also increases. Food security can be realized by shifting patterns of consumption of staple foods to other local food sources (Umanailo, 2018). Food diversification can reduce social inequality, which can be seen from the level of public consumption of food through the index of DDP.

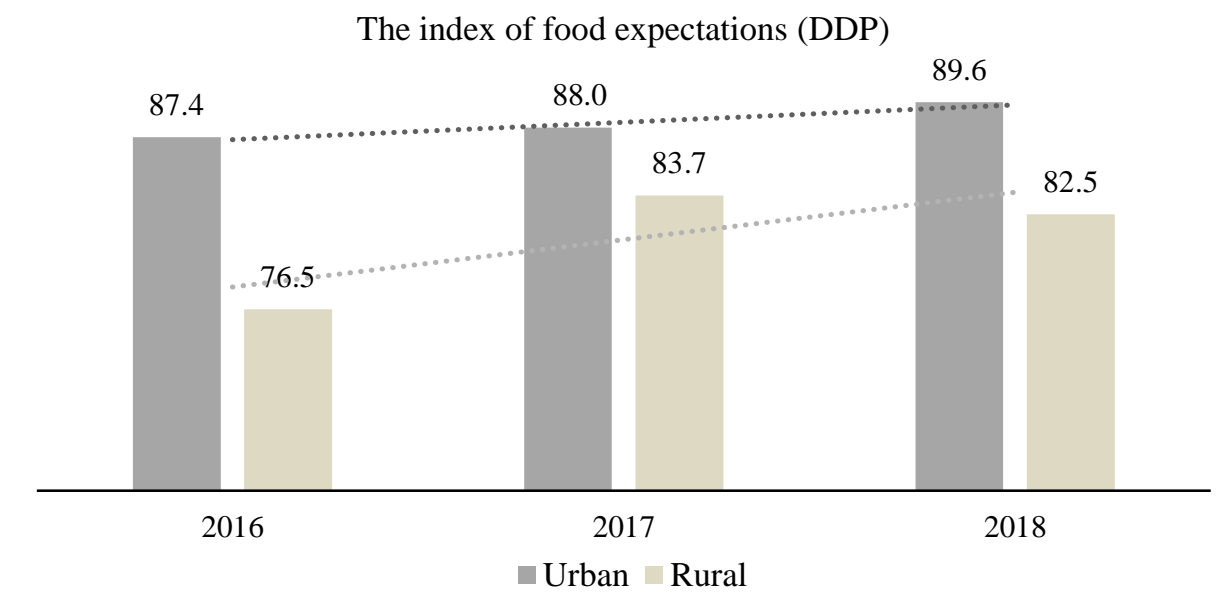

Figure 3. Food pattern expectations of urban and rural populations in Indonesia Source: (BKP, 2019a)

Based on the Figure 3, it can be seen that the food consumption of urban and rural populations is increasing. Food consumption index of the people in rural areas experienced a significant increase from 2016 of 76.5 to 82.5 in 2018 , while the consumption index of urban communities also increased in the same period of 87.4 in 2016 to 89.6 in 2018. The increase in the DDH index indicated increased diversity of food consumption in the population. Food diversification makes food production more varied so that it can increase people's food access. The value of social equality in access to quality food is influenced by the amount of food supply available (Fourat et al., 2020). In this context, food diversification is one of the strategic efforts in poverty alleviation that prioritizes aspects of food supply and access to food; so that social inequalities between rural and urban populations to meet their needs through food consumption can be reduced (Figure 3). High food diversification can increase food accessibility which will have an impact on high food security, so the higher the results of diversification will affect the welfare of the community (Srinita, 2018; Mulwa and Visser, 2019).

The implementation of high food diversification can improve the socio-economic life of the community so that it can reduce the occurrence of social inequality. The ability of the community to well-implement food diversification can lead to a diversity of food production that will have a positive impact on social life and improve the welfare of the household's economic income. In this case, an increase in the results of food diversification will have an impact on increasing productivity and improving the household 
income of farmers which will also contribute to the improvement of the rural economy, so that people's access and purchasing power to food needs also increase (Figure 4).

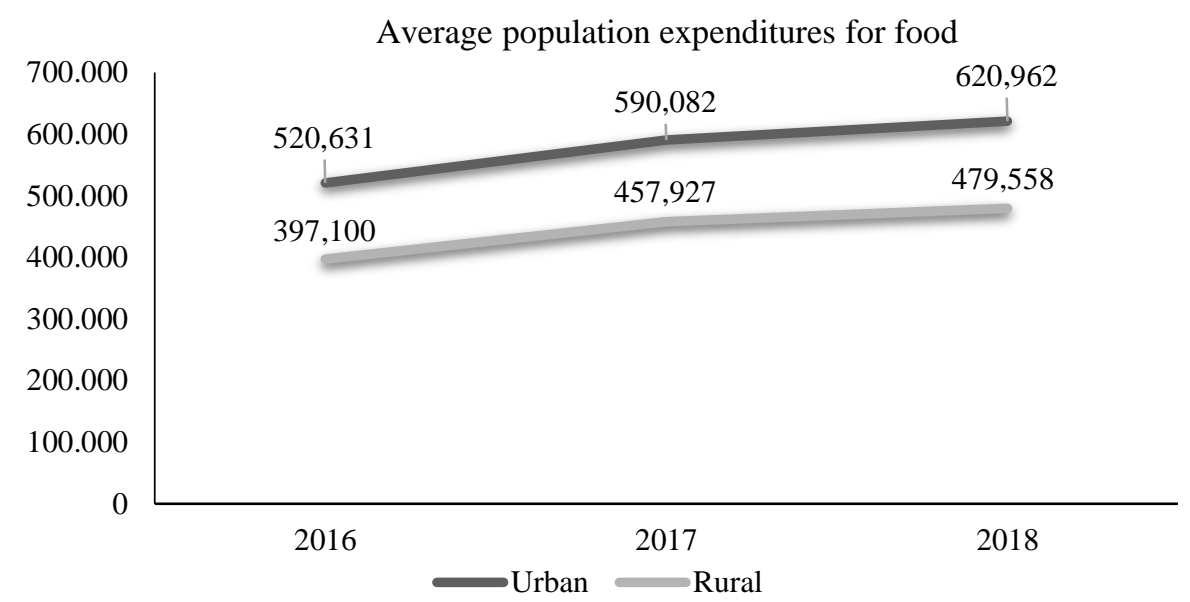

Figure 4. Comparison of population household expenditure rates for food Source: (BKP, 2019a)

Food diversification as a part of efforts to strengthen national food security can be a catalyst for added value to the quality of the results of food preparations. High food diversification from the processing of agricultural products will have an impact on high food security outcomes (Mulwa and Visser, 2019). With the diversity of food available and accessible to the community, it can be utilized to maintain food security through the fulfilment of food sufficiency, reduce socioeconomic inequality and improve people's welfare.

High levels of food diversification will have an impact on food security that can create food security (Mulwa and Visser, 2020). In this context, food diversification has an impact on increasing food production as well as increasing the economic value of food which causes farmers' welfare to improve. It's can be seen through farmers' per capita income. The higher the product produced and supported by the selling value of these food products, the higher the farmer's income.

In 2018, the level of income of farmers was (IDR) 30.37 million per capita, an increase of $4.47 \%$ compared to 2017. The increase in farmers' welfare was also shown by the decreasing number of rural poor people. The percentage of the rural poor population decreased by $4.7 \%$ compared to 2017. In 2017 the number of poor people in the village was 16.31 , while in 2018 it fell to 15.54
(Kementerian Pertanian, 2019). Diversification through diversification of food products as an effective income-increasing strategy and rural poverty reduction strategy (Dev et al., 2017).

\section{CONCLUSIONS}

Food diversification leads to food diversity that can improve economic welfare. In this context, diversification affects increasing production and economic value on food products. The additional economic value of food can increase the income, the resilience of household residents and welfare. Improved welfare can be seen from the decline in the number of rural poor by $4.7 \%$ from 16.31 to 15.54 . It was positively correlated with the increase in farmers' income by (IDR) 30.37 million per capita (4.47\%). Thus, food diversification is one of the instruments that can be used by the government to increase the household income of the population in reducing rural poverty and social inequality.

\section{ACKNOWLEDGEMENTS}

The author thanks to the Department of Government and Public Administration, Universitas Muhammadiyah Yogyakarta. Then, thanks to Abdul Rasyid Ghazali and Al Fauzi Rahmat for suggestions on improving language writing to improve revisions for better article results. 


\section{REFERENCES}

Al-Basith, I. (2019). Relevansi pengembangan sdm untuk wujudkan ketahanan pangan masa depan. KEMENDIKBUD. Retrieved from https://ldikti13.kemdikbud.go.id/2019/03/20/ relevansi-pengembangan-sdm-untuk-wujudka n-ketahanan-pangan-masa-depan/

Azahari, D. H. (2016). Membangun kemandirian pangan dalam rangka meningkatkan ketahanan nasional. Jurnal Analisis Kebijakan Pertanian, 6(2), 174-195. https://doi.org/10.21082/akp. v6n2.2008.174-195

Bandur, A. (2019). Penelitian kualitatif, studi multi-disiplin keilmuan dengan nvivo 12 plus (Edisi Pertama). Jakarta: Mitra Wacana Media.

Bhaduri, S., Sinha, K. M., \& Knorringa, P. (2018). Frugality and cross-sectoral policymaking for food security. Njas - Wageningen Journal of Life Sciences, 84, 72-79. https://doi.org/ 10.1016/j.njas.2017.08.002

BKP. (2019a). Direktori perkembangan konsumsi pangan. Jakarta: Badan Ketahanan Pangan Kementrian Pertanian Indonesia. Retrieved from http://bkp.pertanian.go.id/detail-kategori /detail-buku/direktori-konsumsi-pangan

BKP. (2019b). Situasi ketahanan pangan dan gizi Indonesia tahun 2019. Jakarta: Badan Ketahanan Pangan Kementrian Pertanian Indonesia. Retrieved from http://bkp.pertanian .go.id/storage/app/media/Bahan\%202020/Buk u\%20Situasi\%20Ketahanan\%20Pangan\%20d an\%20Gizi\%202019\%20final.pdf

Cafiero, C., Viviani, S., \& Nord, M. (2018). Food security measurement in a global context: the food insecurity experience scale. Measurement: Journal of the International Measurement Confederation, 116, 146-152. https://doi.org/10.1016/j.measurement.2017.1 0.065

Damanik, S. (2016). Analisis keterkaitan ketahanan pangan dengan kemiskinan berdasarkan implementasi kebijakan penanggulangan kemiskinan di Indonesia. Economics Development Analysis Journal, 5(1), 38-47. https://doi.org/10.15294/edaj.v5 i1.9556

Dev, T., Sultana, N., \& Hossain, E. (2017). Analysis of the impact of income diversification strategies on food security status of rural households in Bangladesh : a case study of Rajshahi District. American Journal of Theoretical and Applied Business, 2(4), 46-56. https://doi.org/10.11648/j.ajtab. 20160204.13

Dewi, E. (2018). Analisis kebijakan swasembada beras dalam upaya peningkatan ketahanan pangan. Jurnal Agribis, 14(1), 29-42. Retrieved from http://journal.unita.ac.id/agri bis/index.php/agribis/article/view/24

FAO, IFAD, UNICEF, WFP, \& WHO. (2018). Food security and nutrition in the world the state of building climate resilience for food security and nutrition. Retrieved from www.fao.org/publications

Fattah, A. N., \& Purnomo, E. P. (2018). Analisis kebijakan alih fungsi lahan pertanian ke nonpertanian di Kabupaten Klaten tahun 20132016 (Studi kasus Kecamatan Ceper Kabupaten Klaten). Jispo, 8(1), 113-140. Retrieved from https://journal.uinsgd.ac.id/ index.php/jispo/article/view/2774

Fourat, E., Closson, C., Holzemer, L., \& Hudon, M. (2020). Social inclusion in an alternative food network: Values, practices and tensions. Journal of Rural Studies, 76, 49-57. https:// doi.org/10.1016/j.jrurstud.2020.03.009

Food Safety Agency. (2018) Rencana kinerja tahunan Badan Ketahanan Pangan tahun 2019. Badan Ketahanan Pangan Kementerian Pertanian. Retrieved from http://bkp.pertanian. go.id/storage/app/media/PPID\%202019/RKT \%202019.pdf

Gerintya, S. (2019). Seberapa kuat ketahanan pangan Indonesia? Retrieved from https://tirto.id/seberapa-kuat-ketahanan-panga n-indonesia-dhNr

Hadi, A., Rusli, B., \& Alexandri, M. B. (2019). Dampak undang-undang nomor 12 tentang pangan terhadap ketahanan pangan Indonesia. Jurnal Responsive, 2(4), 173-181. https://doi .org/https://doi.org/10.24198/responsive.v2i3. 26085

Hanafie, Srd. R., Soetriono, \& Myh, S. R. (2018). Sentra produksi dan diversifikasi pangan olahan berbasis pangan lokal di Jawa Timur. Conference on Innovation and Application of Science and Technology (CIASTECH), 343- 
351. Retrieved from http://publishing-widya gama.ac.id/ejournal-v2/index.php/ciastech/art icle/view/640

Hapsari, N. I., \& Rudiarto, I. (2017). Faktorfaktor yang mempengaruhi kerawanan dan ketahanan pangan dan implikasi kebijakannya di Kabupaten Rembang. Jurnal Wilayah dan Lingkungan, 5(2), 125. https://doi.org/ 10.14710/jwl.5.2.125-140

Hatmanto, T., \& Setyono, J. (2018). Implementasi kebijakan lahan pertanian pangan berkelanjutan (LP2B) melalui penggunaan peta spasial studi kasus di Kabupaten Temanggung, Provinsi Jawa Tengah. Seminar Nasional Geomatika 2018, 735-740. https://doi.org/10.24895/SNG.2018.3-0.1032

Hu, L., Zhao, C., Wang, M., Su, S., Weng, M., \& Wang, W. (2020). Dynamic healthy food accessibility in a rapidly urbanizing metropolitan area: socioeconomic inequality and relative contribution of local factors. Cities, 105(129), 102819. https://doi.org/ 10.1016/j.cities.2020.102819

Ilham, N., Siregar, H., \& Priyarsono, D. S. (2016). Efektivitas kebijakan harga pangan terhadap ketahanan pangan. Jurnal Agro Ekonomi, 24(2), 157. https://doi.org/10.21082/jae.v24n2 .2006.157-177

Jiren, T. S., Dorresteijn, I., Hanspach, J., Schultner, J., Bergsten, A., Manlosa, A., Jager, N., Senbeta, F., \& Fischer, J. (2020). Alternative discourses around the governance of food security: a case study from Ethiopia. Global Food Security, 24, 100338. https:// doi.org/10.1016/j.gfs.2019.100338

Kementerian Pertanian. (2019). Food security and vulnerability atlas 2019. Jakarta: Badan Ketahanan Pangan Kementrian Pertanian Indonesia. Retrieved from URL http://bkp. pertanian.go.id/storage/app/media/Pusat $\% 20$ Ketersediaan/Bidang\%20Ketersediaan/petaketahanan-kerentanan-pangan-2018.pdf?

Kline, K. L., Msangi, S., Dale, V. H., Woods, J., Souza, G. M., Osseweijer, P., ... Mugera, H. K. (2017). Reconciling food security and bioenergy: priorities for action. $G C B$ Bioenergy, 9(3), 557-576. https://doi.org/ 10.1111/gcbb.12366

Larson, J. B., Castellanos, P., \& Jensen, L. (2019).
Gender, household food security, and dietary diversity in Western Honduras. Global Food Security, 20, 170-179. https://doi.org/10.1016/ j.gfs.2019.01.005

Lestari, S., \& Bambang, A. N. (2017). Penerapan minapadi dalam rangka mendukung ketahanan pangan dan meningkatkan kesejahteraan masyarakat. Proceeding Biology Education Conference, 14(1), 70-74. Retrieved from https://jurnal.uns.ac.id/prosbi/article/view/176 16

Miyinzi, C., Mashisia, K., Atibo, C., \& Mwongera, C. (2019). Survey-based data on food security, nutrition and agricultural production shocks among rural farming households in northern Uganda. Data in Brief, 23, 103818. https://doi.org/10.1016/j.dib.2019 .103818

Müller, B., Hoffmann, F., Heckelei, T., Müller, C., Hertel, T. W., Polhill, J. G., ... Webber, H. (2020). Modelling food security: bridging the gap between the micro and the macro scale. Global Environmental Change, 63(March), 102085. https://doi.org/10.1016/j.gloenvcha.2 020.102085

Mulwa, C. K., \& Visser, M. (2020). Farm diversification as an adaptation strategy to climatic shocks and implications for food security in northern Namibia. World Development, 129, 104906. https://doi.org/ 10.1016/j.worlddev.2020.104906

Mulwa, C., \& Visser, M. (2019). Farm diversification and climate change: implications for food security in northern Namibia. 6th African Conference of Agricultural Economists, 1-23. https://doi.org/ 10.22004/ag.econ.295846

Perdinan, Atmaja, T., Adi, R. F., \& Estiningtyas, W. (2018). Adaptasi perubahan iklim dan ketahanan pangan: telaah inisiatif dan kebijakan. Jurnal Hukum Lingkungan Indonesia, 5(1), 60-87. http://dx.doi.org/ 10.38011/jhli.v5i1.75

Purnomo, E. P., Ramdani, R., Agustiyara, Tomaro, Q. P. V., \& Samidjo, G. S. (2019). Land ownership transformation before and after forest fires in Indonesian palm oil plantation areas. Journal of Land Use Science, 14(1), 37-51. https://doi.org/10.1080/174742 


\section{X.2019.1614686}

Rafiuddin, A., Widiatmaka, \& Munibah, K. (2016). Pola perubahan penggunaan lahan dan neraca pangan di Kabupaten Karawang. Jurnal Ilmu Tanah Dan Lingkungan, 18(1), 15-20. Retrieved from http://jesl.journal.ipb.ac.id/ index.php/jtanah/article/view/12641/13553

Rofiq, A., \& Subagi, A. (2016). Pengembangan potensi lokal untuk bahan baku pangan dan industri sebagai usaha meningkatkan ketahanan pangan nasional. Jurnal Pangan, 18(54), 36-43. http://dx.doi.org/10.33964/jp. v18i2.202

Rusdiana, S., \& Maesya, A. (2017). Pertumbuhan ekonomi dan kebutuhan pangan di Indonesia. Agriekonomika, 6(1), 12-25. https://doi.org/ 10.21107/agriekonomika.v6i1.1795

Sadali, M. I. (2018). Ketahanan pangan berkelanjutan di Kabupaten Sukoharjo. Jurnal Pendidikan Geografi, 10(1), 86-97. https:// doi.org/10.24114/jg.v10i1.8493

Saliem, H. P., \& Ariani, M. (2016). Ketahanan pangan, konsep, pengukuran dan strategi. Forum Penelitian Agro Ekonomi, 20(1), 1224. https://doi.org/10.21082/fae.v20n1.2002. $12-24$

Saragih, J. P. (2017). Kelembagaan urusan pangan dari masa ke masa dan kebijakan ketahanan pangan. Jurnal Ekonomi \& Studi Pembangunan, 17(2), 57-80. https://doi.org/ 10.18196/jesp.17.2.3983
Sellberg, M. M., Norström, A. V., Peterson, G. D., \& Gordon, L. J. (2020). Using local initiatives to envision sustainable and resilient food systems in the Stockholm City-Region. Global Food Security, 24, 100334. https://doi.org/ 10.1016/j.gfs.2019.100334

Srinita. (2018). Factor affecting of food security and community welfare of farmer households in Sumatera, Indonesia. World Journal of Science, Technology and Sustainable Development, 15(2), 200-212. https://doi.org/ 10.1108/WJSTSD-10-2017-0037

Umanailo, M. C. B. (2018). Ketahanan pangan lokal dan diversifikasi konsumsi masyarakat (studi pada masyarakat Desa Waimangit Kabupaten Buru). Soca: Jurnal Sosial Ekonomi Pertanian Dan Agribisnis, 12(1), 63 -74. https://doi.org/10.24843/soca.2018.v12.i 01.p05

Waha, K., van Wijk, M. T., Fritz, S., See, L., Thornton, P. K., Wichern, J., \& Herrero, M. (2018). Agricultural diversification as an important strategy for achieving food security in Africa. Global Change Biology, 24(8), 3390-3400. https://doi.org/10.1111/gcb .14158

Widodo, Wijaya, O., Indardi, \& Akhmadi, H. (2018). Identifikasi ketahanan pangan berdasar aspek akses pangan di Kabupaten Batang. Seminar Nasional Dies Natalis UNS Ke 42, 2(1), 154-161. Retrieved from https:// jurnal.fp.uns.ac.id/index.php/semnas/article/vi ew/1158 